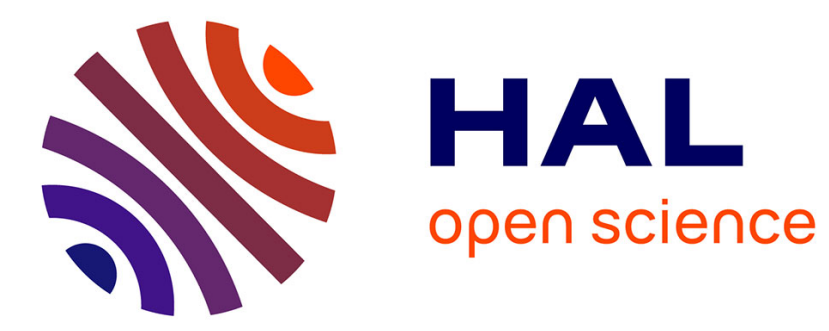

\title{
Molecular and morphological data support reclassification of the octocoral genus Isidoides
}

Eric Pante, Esprit Heestand-Saucier, Scott France

\section{To cite this version:}

Eric Pante, Esprit Heestand-Saucier, Scott France. Molecular and morphological data support reclassification of the octocoral genus Isidoides. Invertebrate Systematics, 2013, 27, pp.365-378. 10.1071/IS12053 . hal-00874705

\section{HAL Id: hal-00874705 https://hal.science/hal-00874705}

Submitted on 18 Oct 2013

HAL is a multi-disciplinary open access archive for the deposit and dissemination of scientific research documents, whether they are published or not. The documents may come from teaching and research institutions in France or abroad, or from public or private research centers.
L'archive ouverte pluridisciplinaire HAL, est destinée au dépôt et à la diffusion de documents scientifiques de niveau recherche, publiés ou non, émanant des établissements d'enseignement et de recherche français ou étrangers, des laboratoires publics ou privés. 
Publisher: CSIRO; Journal: IS:Invertebrate Systematics

Article Type: research-article; Volume: ; Issue: ; Article ID: IS12053

DOI: 10.1071/IS12053; TOC Head:

\section{Molecular and morphological data support reclassification of the octocoral genus Isidoides}

\section{Eric Pante ${ }^{\mathrm{A}, \mathrm{B}, \mathrm{C}}$, Esprit Heestand Saucier ${ }^{\mathrm{A}}$ and Scott C. France $^{\mathrm{A}}$}

${ }^{A}$ Department of Biology, University of Louisiana at Lafayette, PO Box 42451, Lafayette LA 70504, USA.

${ }^{B}$ Present address: Littoral, Environnement et Sociétés (LIENSs), UMR 7266 CNRS, Université de La

Rochelle, 2 rue Olympe de Gouges, 17042 La Rochelle, France.

${ }^{\mathrm{C}}$ Corresponding author. Email: pante.eric@gmail.com

The rare octocoral genus Isidoides Nutting, 1910 was originally placed in the Gorgonellidae (now the Ellisellidae), even though it showed a remarkable similarity to the Isidae (now the Isididae). Isidoides was not classified in the Isididae mostly because the type specimen lacked skeletal nodes, a defining characteristic of that family. The genus was later assigned to the Chrysogorgiidae based on sclerite morphology. Specimens were recently collected in the south-western Pacific, providing material for genetic analysis and detailed characterisation of the morphology, and allowing us to consider the systematic placement of this taxon within the suborder Calcaxonia. A previously reported phylogeny allowed us to reject monophyly with the Chrysogorgiidae, and infer a close relationship with the Isididae subfamily Keratoisidinae. While scanning for molecular variation across mitochondrial genes, we discovered a novel gene order that is, based on available data, unique among metazoans. Despite these new data, the systematic placement of Isidoides is still unclear, as (1) the phylogenetic relationships among Isididae subfamilies remain poorly resolved, (2) genetic distances between mitochondrial $m t M u t S$ sequences from Isidoides and Keratoisidinae are characteristic of intra-familial distances, and (3) mitochondrial gene rearrangements may occur among confamilial genera. For these reasons, and because a revision of the Isididae is beyond the scope of this contribution, we amend the familial placement of Isidoides to incertae sedis.

IS12053

E. Pante et al.

Revisionary systematics of Isidoides

The deep-sea octocoral Isidoides has not been reported since its original description in 1910. Recent collections in the SW Pacific have provided fresh specimens, revealed a novel mitochondrial gene order and allowed us to reject monophyly with the Chrysogorgiidae. However, systematic placement of Isidoides is still unclear, so we amend its familial placement to incertae sedis.

Received 30 June 2012, accepted 4 February 2013, published online dd mmm yyyy

Additional keywords: Calcaxonia, Chrysogorgiidae, mitochondrial gene order, Isididae, Octocorallia, tropical deep-sea benthos. 
Publisher: CSIRO; Journal: IS:Invertebrate Systematics

Article Type: research-article; Volume: ; Issue: ; Article ID: IS12053

DOI: 10.1071/IS12053; TOC Head:

\section{Introduction}

In his examination of the gorgonian octocorals from the Siboga expedition, Nutting (1910) described a new genus and species of Gorgonellidae (now Ellisellidae), Isidoides armata, based on fragments of a single specimen collected in the lee of the island of Nuhu Cut (Indonesia, Arafura Sea). He noted its unusual morphology: 'This remarkable form shows a close resemblance to certain Isidae, and would be placed in that family were the axis jointed. It also shows an approach to the Primnoidae in the character of the operculum'. In particular, the author noted that sclerites 'resemble in form certain spicules found in the Isidae, e.g. Bathygorgia profunda, but are smoother than any others that the writer has seen'. Bayer and Stefani (1988) later noted that the fine scales of Isidoides are typical of the Chrysogorgiidae.

Isidoides appears in a key of the Chrysogorgiidae as early as 1979 (Bayer 1979), but no justification was given for the placement of the genus in that family, suggesting that Isidoides was removed from the Ellisellidae before that date. Later, Bayer and Grasshoff (1994) clearly stated that Isidoides should belong to the Chrysogorgiidae rather than the Ellisellidae, but did not reference previous work. Regardless of its final placement in the Chrysogorgiidae, Ellisellidae, Primnoidae or Isididae, this taxon is of particular interest because the set of morphological characters that characterises it challenges the diagnosis of some calcaxonian families, and may allow further discussion of character evolution, such as axial articulation.

The holotype material of Isidoides armata is a collection of small fragments (now held at the Naturalis Biodiversity Center of Amsterdam). In 2003, a new specimen of Isidoides, identified by Phil Alderslade, was collected on the Norfolk Ridge during the NORFANZ Project (Williams et al. 2006). The same year, researchers from the French National Museum of Natural History (MNHN), conjointly with the Institute of Research for Development (IRD), independently collected on the Norfolk Ridge a specimen of Isidoides that remained in the MNHN collections, unidentified, until 2007. In 2008 and 2011, during the MNHN cruises Terrasses and ExBoDi in New Caledonia, five additional specimens were collected. This paper is part of a larger effort to describe the octocoral material collected during these cruises. We herein analyse the taxonomic and phylogenetic location of Isidoides in the suborder Calcaxonia, and present data that show that its familial placement is currently debatable, therefore classifying it as incertae sedis.

\section{Materials and methods}

Specimen collection

This study is based on the examination of specimens collected from: (1) New Zealand and the Norfolk Ridge (NORFANZ Project; NIWA collection specimens; 2000-04); and (2) New Caledonia and the Norfolk and Loyalty Ridges (MNHN/IRD, Tropical Deep-Sea Benthos cruises; 2003-12), with comparisons to type material collected in the Arafura Sea during the Siboga expedition (Fig. 1; Nutting 1910). A colony fragment from the type material (in his description, Nutting detailed that the material 
Publisher: CSIRO; Journal: IS:Invertebrate Systematics

Article Type: research-article; Volume: ; Issue: ; Article ID: IS12053

DOI: 10.1071/IS12053; TOC Head:

observed was fragmentary) was loaned to us by the Zoological Museum of the University of Amsterdam (the type material is now at the Naturalis Biodiversity Center in Amsterdam). While examining this type material, we encountered a discrepancy between the station information cited in Nutting's (1910) monograph (Station $267,5.9^{\circ} \mathrm{S}, 132.94^{\circ} \mathrm{E}, 984 \mathrm{~m}$ depth), and that shown on the hand-written label (the presumed original label) included with the types at the Zoological Museum of the University of Amsterdam, ZMA Coel. 02711 (Station 297, 10.65으. $123.67^{\circ} \mathrm{E}, 520 \mathrm{~m}$ depth). The type fragment we examined was not the one illustrated and described by Nutting (Fig. 2; note that Nutting's illustrated fragment now exists as two pieces). Because it cannot be asserted that all the fragments observed by Nutting came from the same colony (particularly given the station discrepancy), we propose that Nutting's illustrated fragment (Fig. 2) be designated as the lectotype, and our illustrated fragment (Fig. 3) be designated as a paralectotype. Other specimens are deposited at the MNHN (Paris, France) and the NIWA Invertebrate Collection (NIC; Wellington, New Zealand). All colonies are preserved in ethanol, and are listed in Table 1.

\section{Genetic analyses}

Genomic DNA was purified from ethanol-preserved tissue using a modified CTAB-extraction protocol (France et al. 1996). The mitochondrial genes mtMutS (formerly called msh1; Bilewitch and Degnan 2011), cox 1 and $c y t b$, and the nuclear $18 \mathrm{~S}$ gene, were amplified and sequenced for phylogenetic analyses (primers, PCR protocol and tree inference detailed in Pante et al. 2012a). We attempted to determine $m t M u t S$ haplotypes (i.e. unique sequences of haploid mitochondrial DNA) for all specimens using the following primer pairs, amplifying the $5^{\prime}$ and $3^{\prime}$ ends of the gene: ND42475F-MUT3458R and MSH4759F-16S5PR (first $697 \mathrm{bp}$ and last $800 \mathrm{bp}$ of the gene; Table 2). Mitochondrial gene boundaries were tested using the primers in Table 2. DNA sequence traces were examined and edited using Sequencher ver. 4.7 (Gene Codes Corp., Ann Arbor, MI, USA), and aligned using MAFFT (L-INS-i method; Katoh et al. 2002; Katoh and Toh 2008). All new haplotypes and genotypes were submitted to GenBank (Table 1). Divergence among clades was measured using the Kimura-2-parameter (K2P) model of nucleotide substitution (Kimura 1980) using the ape package (Paradis 2006) in R (R Development Core Team 2012). This model was used because it is relatively simple (relies on two parameters only), was used previously to measure clade divergence among calcaxonians (Pante and France 2010), and is a widely used metric in DNA barcoding (Hebert et al. 2003), particularly when genetic distances are low (Nei and Kumar 2000). We appended the sequences produced here (Table 1) to the data from 48 calcaxonian sequences analysed in McFadden et al. (2011). 
Publisher: CSIRO; Journal: IS:Invertebrate Systematics

Article Type: research-article; Volume: ; Issue: ; Article ID: IS12053

DOI: 10.1071/IS12053; TOC Head:

\section{Morphology}

The photographs of specimens in Figs 4 and 5 show colonies after removal of branches or polyps for genetic analyses (clippings were made at sea at the time of collection; genetic analysis of the paralectotype was attempted on damaged polyps that were already detached from the branch).

Measurements (e.g. colony height and width) were taken directly on the colony when possible, or from photographs using the program ImageJ (Rasband 1997-2008; Abramoff et al. 2004), when measuring directly was not practical (e.g. measurement of angles). Measurements of sclerites were done from light microscope imagery using ImageJ. Sclerite lengths are reported as mean \pm one standard error. Some polyps were incubated in a solution of $5 \%$ glutaraldehyde (buffered with $\mathrm{KH}_{2} \mathrm{PO}_{4}$ and $\mathrm{Na}_{2} \mathrm{HPO}_{4}$ at $\mathrm{pH}$ 6.8) overnight to help anchor sclerites to the tissues (Pante and France 2010). They were then exposed to $20 \%$ bleach for a few seconds to dissolve the epithelium covering the sclerites to make their arrangement more visible. Polyps were placed in $100 \%$ hydrogen peroxide for a few seconds to further help shake off remaining pieces of tissue, and placed in $100 \%$ dry acetone for $12 \mathrm{~h}$ for dehydration. Polyps were then mounted on SEM stubs using double-faced carbon tape, and allowed to air dry in a hood for at least $12 \mathrm{~h}$. Polyps were sputter-coated with $10 \mathrm{~nm}$ of gold to reduce charging. Sclerites were prepared as in Pante and France (2010). Digital images of sclerites and polyps were generated using a Hitachi S-3000N scanning-electron microscope (Hitachi Science Systems, Ltd, Japan). Measurements (presented separately for the type ZMA material and all other specimens) are reported \pm one standard error. The $n$ values below correspond to the number of measurements taken.

\section{Results}

\section{Molecular variation}

Molecular variation among Isidoides specimens was minimal at both mitochondrial and nuclear loci. Three haplotypes (named A, B and C) were detected for $m t M u t S$ (2914 bp). Haplotypes A and B were separated by a single substitution at position 165 of the gene, corresponding to the 3 rd position of a codon coding for valine. Haplotype C differed from A and B at position 2103, corresponding to the 3rd position of a codon coding for serine. Both mutations are silent. While no morphological variation could be reliably used to distinguish haplotypes $\mathrm{A}$ and $\mathrm{B}$, haplotype $\mathrm{C}$ (specimen TER1061) is characterised by a dark golden-brown-coloured axis, while specimens of haplotypes A and B have a creamy-coloured axis. No additional variation was detected among Isidoides specimens for the markers coxl, cytb and 18S. Despite numerous attempts, no reliable DNA sequence could be produced for the paralectotype. Figure 6 shows that the range of genetic distances between Isidoides and isidids (subfamily Keratoisidinae and the S1 clade only; see Fig. 7) overlaps both distributions of inter- and intra-familial distance. While distances involving Isidoides and isidids are completely within the range of intra-familial, inter-generic distances, they only partially overlap the distribution of inter-familial distances. 
Publisher: CSIRO; Journal: IS:Invertebrate Systematics

Article Type: research-article; Volume: ; Issue: ; Article ID: IS12053

DOI: 10.1071/IS12053; TOC Head:

\section{Gene order in Calcaxonia}

We examined additional mitochondrial gene regions for variation between the two Isidoides morphotypes differentiated by their axes (dark vs light) using primer pair combinations that spanned gene junctions based on the most common gene order of Octocorallia (see McFadden et al. 2010: fig. 4). Polymerase chain reaction products of expected size were obtained for the regions spanning cob-nad6, nad4l-mtMutS, $m t M u t S-16 \mathrm{~S}$, as well as cox1-cox2. However, no PCR products were obtained for the regions spanning cox3 to nad4, and cob to nadl. We tested alternative combinations of primers that annealed to these four genes and obtained PCR products using the following combinations: a forward primer annealing in the $3^{\prime}$ end of $\operatorname{cox} 3$ with a reverse primer at the $5^{\prime}$ end of $\operatorname{cob}\left(\sim 1000 \mathrm{bp}\right.$ amplicon), and a forward primer in the $3^{\prime}$ end of nad4 with a second forward primer in the 3 ' end of $\operatorname{nadl}(\approx 650 \mathrm{bp})$. 'Forward' refers to the direction of translation and thus an amplicon resulting from two forward primers indicates the two genes are on opposite strands. While we did not observe any variation in these gene regions between the two Isidoides morphotypes, direct sequencing confirmed that: (1) nadl and nad4 are separated by a $78 \mathrm{bp}$ inter-genic region (IGR), and (2) cox3 and $c o b$ are separated by a 485 bp IGR that contains a tRNA(Met) (71 bp). This arrangement of genes (Fig. 7) has not previously been reported in cnidarians (Flot and Tillier 2007; Brugler and France 2007, 2008; Chen et al. 2008a, 2008b; Kayal and Lavrov 2008; Uda et al. 2011; Park et al. 2011; Brockman and McFadden 2012; Kayal et al. 2012), and a search on the MitoZoa gene order database (Lupi et al. 2010; D’Onorio de Meo et al. 2012) failed to detect the 'cox3tRNA(Met)-cob' arrangement among the metazoan mitogenomes sequenced to date.

The genes involved in the novel rearrangement observed in Isidoides (nad1-nad4, cox3-cob) are not routinely PCR-amplified in octocoral phylogenetic studies (except for cox3-mtMutS in the Keratoisidinae (van der Ham et al. 2009) and cob-nad6 in the Primnoidae, (J. L. van der Ham and S. C. France, unpubl. data)). We therefore tested for the presence of the novel gene junctions observed in Isidoides in other calcaxonians phylogenetically close to this taxon: the monophyletic Chrysogorgiidae clade (MCC, as defined in Pante et al. 2012a), the Primnoidae, Trichogorgia, and a clade of isidids (S1 clade; Fig. 7) that is sister to the Keratoisidinae (which are characterised by their own unique mitochondrial gene arrangement; Brugler and France 2008; van der Ham et al. 2009). None of these taxa produced amplicons when using primer combinations reflecting the Isidoides gene order. All amplicons were produced using primer combinations that reflect the most common octocorallian gene order (see McFadden et al. 2010: fig. 4). 


\title{
Taxonomy
}

Subclass OCTOCORALLIA Haeckel, 1866

Order ALCYONACEA Lamouroux, 1816

Suborder CALCAXONIA Grasshoff, 1999

\author{
Family incertae sedis
}

Genus Isidoides Nutting, 1910

(Figs 2-5, 8-10; Table 1)

Type species: Isidoides armata Nutting, 1910 by original designation and monotypy.

\section{Diagnosis}

Pseudo-dichotomously branching calcaxonian. Axis formed of concentric layers, not hollow, white or dark golden-brown in colour, not articulated. Polyps biserially oriented (with a single polyp found along each side of the biserial arrangement), with exceptions, and non-retractile. Sclerites smooth and in the shape of flattened rods, found on polyp tentacles (longitudinally arranged and imbricated) and body walls (longitudinally and diagonally arranged), in the branch coenenchyme (longitudinally arranged), rarely in the pharynx.

\section{Material examined}

ZMA Coel. 02711, paralectotype by present designation (based on Nutting's (1910) monograph, collected on 20.xii.1899 on the eastern slope of Elat, Kei Islands, Arafura Sea; Siboga expedition, station 267, $984 \mathrm{~m}$ depth, $5.9^{\circ} \mathrm{S} 132.945^{\circ} \mathrm{E}$; however, the label associated with the type material indicates collection from a shallower depth $\sim 1200 \mathrm{~km}$ further to the south-west, south of the western tip of Timor: Station $297,520 \mathrm{~m}$ depth $10.65^{\circ} \mathrm{S}, 123.67^{\circ} \mathrm{E}$ ), and all other specimens listed in Table 1 .

\section{Description}

Colonies are planar with irregular pseudo-dichotomous branching (following the terminology defined in Alderslade 1998). Branches following a fork curve upwards, parallel to each other. Colony size is unknown, as only fragments have been collected and in situ photographs were not taken. The largest known fragment is $36 \mathrm{~cm}$. No information is available on the holdfast. The diameter of the axis ranges from 0.1 to $2.9 \mathrm{~mm}(n=95$, mean $=1.0 \pm 0.1$; ZMA Coel. 02711: $n=21,0.8-2.5$, mean $=1.6 \pm 0.1)$. Axes are found in two colour morphs: cream, and dark golden-brown to black. They are formed of 
Publisher: CSIRO; Journal: IS:Invertebrate Systematics

Article Type: research-article; Volume: ; Issue: ; Article ID: IS12053

DOI: 10.1071/IS12053; TOC Head:

concentric layers, and are not characterised by a hollow centre (Fig. $8 A$ ). At the very thin distal end of the twigs circular pits are present, $10-30 \mu \mathrm{m}$ in diameter, which decrease in prevalence with distance from the tip (Fig. 8B). Axes appear smooth when examined by eye or with a dissection microscope, but thick areas can appear pitted when looked at with SEM (Fig. 8C).

The tissue-covered branches have a uniform diameter throughout the colony; however, the axis is thinner towards branch tips and the coenenchyme is thicker (or compensates by being thicker), e.g. coenenchyme is thinner on the older parts of the colony. Anastomosis of branches was never observed. The distance between branching points varies between 3.6 and $124.4 \mathrm{~mm}(n=74$; mean $=35.7 \pm 2.8$; ZMA Coel. 02711: $n=3,22.8-26.2$, mean $=24.8 \pm 1$ ), and the length of terminal branchlets varies between 4.3 and $178.9 \mathrm{~mm}(n=80$; mean $=43.5 \pm 3.7$; ZMA Coel. 02711: no terminal branchlet available; measurements from Nutting's original illustration (Fig. 2): $n=4,15.0-38.9$, mean $=21.7 \pm$ 5.7).

Polyps are yellow to light brown immediately following collection, and become paler when preserved in ethanol. The distal ends of polyps tend to be darker. Polyps are uniformly tubular in shape with a slight bulge distally; in contraction the tentacles are tightly folded over the oral disc. Polyp length varies from 1.0 to $5.9 \mathrm{~mm}(n=710$; mean $=2.8 \pm 0.03$; ZMA Coel. $02711: n=41,1.2-4.7$, mean $=2.5 \pm 0.1)$, and width varies from 0.4 to $2.2 \mathrm{~mm}(n=720$; mean $=1.1 \pm 0.01$; ZMA Coel. 02711: $n=41,0.4-1.4$, mean $=$ $0.9 \pm 0.03)$. Polyps are uniform in shape. As described by Nutting, 'ordinarily they are tubular when retracted and club-shaped when expanded, but the distal ends are almost always enlarged, even in retraction'. They are essentially distributed biserially with two single opposing rows of polyps, which are alternately arranged. Most polyps arise parallel to the colony plane, and curve in the same direction out of the plane towards the front of the colony; occasionally polyps arise perpendicular to the colony plane, on its front, between the biserial rows. Polyps are completely absent from the back of the colony (front and back are used as defined in Bayer et al. 1983). The distal portion of polyps is bent towards the top of the colony. Polyps are separated by 0.1 to $4.8 \mathrm{~mm}(n=100$; mean $=1.1 \pm 0.1$; ZMA Coel. 02711: $n=32$, $1.3-4.4$, mean $=2.6 \pm 0.1$ ). The semitransparent coenenchyme ranges from white to yellow; when preserved it remains white or turns light tan.

Sclerites are densely packed in the branch coenenchyme and polyps. Most are finger biscuit-shaped (i.e. flattened rods), and crosses are occasionally encountered (Figs 9-10). Sclerites from the branch coenenchyme and body wall range in length from 0.04 to $0.50 \mathrm{~mm}(n=897$; mean $=0.16 \pm 0.002$; ZMA Coel. 02711: $n=100,0.05-0.28$, mean $=0.12 \pm 0.003)$ and from 0.02 to $0.44(n=1094$; mean $0.15 \pm$ 0.002; ZMA Coel. 02711: $n=100,0.09-0.31$, mean $=0.22 \pm 0.005)$, respectively. They are longitudinally or diagonally arranged on the polyp, criss-crossing in most colonies, particularly towards 
Publisher: CSIRO; Journal: IS:Invertebrate Systematics

Article Type: research-article; Volume: ; Issue: ; Article ID: IS12053

DOI: 10.1071/IS12053; TOC Head:

the distal end of the polyp (as described by Nutting 1910), while they are longitudinally arranged in the coenenchyme (Fig. 10). Smaller sclerites ( 0.02 to $0.41 \mathrm{~mm} ; n=1243$; mean $=0.08 \pm 0.002$; ZMA Coel. 02711: $n=100,0.04-0.28$, mean $=0.12 \pm 0.01)$ cover the back of tentacles. They are mostly positioned longitudinally along the tentacle, some being imbricated in a seemingly disorderly fashion. Nutting (1910) referred to the folded-over, sclerite-laden tentacles as an operculum or pseudo-operculum. When exposed to polarised light, sclerites are characterised by concentrically arranged interference colours (see Bayer 1956: fig. 158-6).

\section{Remarks}

As with the material described by Nutting (1910), our descriptions come from fragments of colonies.

About the holdfast, Nutting noted: 'the base is lacking; although it is partly retained in another, where it is solidly calcareous'. However, only a single specimen of Isisoides armata was listed by the author, and the paralectotype acquired from the Zoological Museum at the University of Amsterdam lacked its base as well. Sequencing of non-type material revealed that the mitochondrial gene order includes the following gene junctions: cox3-cytb, nad1-nad4 and nad4L-mtMutS. Finally, the axes of two specimens (the paralectotype and NOR220652) include single node-like features (Fig. 3). These features are discoloured bulges in the continuous axis that appear to be overgrowths rather than proteinaceous nodes as in the Isididae. Peeling away the upper layers of these bulges revealed unconsolidated soft tissue within. The node-like feature of NOR220652 is a hollow pouch containing two copepods (a large female and a small male).

\section{Distribution}

Isidoides is thus far known only from the western Pacific Ocean. First sampled in the Arafura Sea, SW of the island of New Guinea (Table 1), with recent collections from around New Caledonia and New Zealand, over $5600 \mathrm{~km}$ from the type locality, it has a latitudinal range of at least 30 degrees. Isidoides has been collected as deep as 1035-1065 $\mathrm{m}$ and as shallow as $645 \mathrm{~m}$ depth, although its shallowest occurrence is unknown: it might have been collected by the Siboga crew from $520 \mathrm{~m}$ depth (see 'Materials and methods'). Its habitat is unknown; however, we hypothesise it is found on hard substrates, as specimens adapted to this habitat were collected in the same trawls during the Terrasses cruise (e.g. Chrysogorgia Duchassaing \& Michelotti, 1864, Calyptrophora Gray, 1866 and Narella Gray, 1870). All three $m t M u t S$ haplotypes were found in sympatry on the Loyalty Ridge, at very similar depths (700-800 $\mathrm{m})$. 
Publisher: CSIRO; Journal: IS:Invertebrate Systematics

Article Type: research-article; Volume: ; Issue: ; Article ID: IS12053

DOI: 10.1071/IS12053; TOC Head:

\section{Discussion}

Isidoides should not be classified with the Chrysogorgiidae

Our previous findings based on phylogenetics and morphology of Isidoides strongly support that this genus is not a chrysogorgiid coral (Pante et al. 2012a). First, a molecular phylogeny based on the mitochondrial $m t M u t S$ and coxl, and the nuclear $18 \mathrm{~S}$ genes, provides strong support of the polyphyly of the Chrysogorgiidae (Fig. 7; Pante et al. 2012a), with Isidoides being more closely related to the subfamily Keratoisidinae (Isididae Lamouroux, 1812) than to any chrysogorgiid genus. The monophyletic Chrysogorgiidae clade (MCC) is composed of Chrysogorgia, Radicipes Stearns, 1883, Pseudochrysogorgia Pante \& France, 2010, Iridogorgia Verrill, 1883, Rhodaniridogorgia Watling, 2007 and Metallogorgia Versluys, 1902. These genera share an iridescent and spiralling main axis, unserially arranged, slender polyps separated by a thin layer of coenenchyme, and sclerites in the form of rods, plates, scales and needles with little ornamentation. The small, smooth sclerites of Isidoides resemble those of chrysogorgiids of the MCC (particularly Metallogorgia). However, the axis of Isidoides contrasts sharply with that of MCC taxa, as it is not iridescent, and has alternatively a white to dark golden-brown appearance. Neither the axis nor the branches of Isidoides appear to form a spiral, and colonies lack the geometric organisation that characterises genera such as Chrysogorgia and Pseudochrysogorgia. Isidoides coenenchyme is thick, heavily packed with sclerites, and the axis is rarely visible without dissection of the tissue. Polyps are biserially arranged (very often with poor alignment among polyp pairs), a character state that was never observed among specimens of the MCC. Morphological differences between Isidoides and the MCC are therefore substantial, and are on par with the phylogenetic differences observed. In addition, the mitochondrial gene arrangement in Isidoides is different from that found in the MCC, for which no variation in mitochondrial gene order has been observed to date (Pante et al. 2012a).

Should Isidoides be classified with the Isididae?

As noted above, our molecular phylogeny shows that, among calcaxonian taxa, Isidoides is most closely related to Isididae in the subfamily Keratoisidinae. Ignoring for a moment that Isidoides lacks proteinaceous nodes on the axis, the morphology of its polyps and sclerites conforms quite well to the newly revised definition of the Keratoisidinae (Alderslade and McFadden 2012). This subfamily is differentiated from the others in the Isididae by sclerites in the form of needles, spindles, rods, or scales (the case in Isidoides), oriented longitudinally or obliquely (the case in Isidoides). The sclerite types of the Isidinae, Mopseinae and Circinisidinae are very different, taking the form of clubs, tuberculate spindles or scales, and are transversely arranged. 
Publisher: CSIRO; Journal: IS:Invertebrate Systematics

Article Type: research-article; Volume: ; Issue: ; Article ID: IS12053

DOI: 10.1071/IS12053; TOC Head:

Measuring genetic distances between Isidoides and genera of the Keratoisidinae/S1 clade revealed a range of values that was fully overlapping with the range of distances found among comparisons between keratoisidin genera. However, Isidoides-Isididae distances were only partially overlapping with distances measured between species from different calcaxonian families ('inter-familial' distances). Based on these distances alone, it might therefore be most parsimonious to consider Isidoides as a new genus of the Isididae (and more specifically, the Keratoisidinae). However, placing Isidoides in the Isididae is problematic because it lacks the articulated axis diagnostic of that family. To accommodate the inclusion of Isidoides in the subfamily Keratoisidinae, we would therefore have to re-define the diagnosis of the family Isididae. Much evidence is accumulating that the Isididae is polyphyletic and does need revising (S. C. France and L. Watling, unpubl. data; Alderslade and McFadden 2012; Pante et al. 2012a), but noting that the deep phylogenetic nodes separating isidid subfamilies are not fully resolved. In particular, molecular phylogenetic analyses show that axis articulation has evolved multiple times in the Octocorallia, and even within the Calcaxonia is not a synapomorphy of the Isididae or Keratoisidinae (S. C. France and E. Heestand Saucier, unpubl. data on the Isididae; S. C. France and J. L. van der Ham, unpubl. data on the Primnoidae). If a family revision recognises variation in axis articulation, Isidoides could then be included in the Keratoisidinae.

\section{Should Isidoides be elevated into a new family?}

Although the genetic distances between Isidoides and other isidids of the Keratoisidinae and the S1 clade are fully within the range of inter-generic, intra-familial comparisons, they also overlap the lower range of the distances measured between chrysogorgiids, primnoids and isidids. Therefore, based on genetic distance it may be justifiable to erect a new family to accommodate Isidoides and its non-articulated axis. However, genetic distance as a yardstick of evolutionary history should be interpreted with care, as the rate at which mutations accumulate may not be constant across the calcaxonian tree (this, however, has never been tested, as fossil records are sorely lacking for the Octocorallia). Second, in the phylogenetic tree based on genetic data the Isidoides clade is sister to the Keratoisidinae and S1 clades. As deep nodes separating the different isidid subfamilies are hard to resolve (Pante et al. 2012a; E. Heestand Saucier and S. C. France, unpubl. data), it cannot be excluded that future, better-resolved multi-gene phylogenies may support the monophyly of some subfamilies (e.g. Mopseinae, Isidoides, S1, Keratoisidinae; see Fig. 1 of Alderslade and McFadden 2012). Last, the unique mitochondrial gene order found in Isidoides emphasises its special status within the Calcaxonia. While gene order rearrangements have also been observed among taxa from different families, intra-familial rearrangements have occasionally been found (e.g. Corallium and Paracorallium; Uda et al. 2011; Paragorgia and Sibogagorgia; J. N. Thoma, M. R. Brugler and S. C. France, unpubl. data). For all these reasons, including practicality (as the Isididae is 
Publisher: CSIRO; Journal: IS:Invertebrate Systematics

Article Type: research-article; Volume: ; Issue: ; Article ID: IS12053

DOI: 10.1071/IS12053; TOC Head:

currently being revised by Heestand Saucier, Watling and France), we decided to amend the taxonomic placement of Isidoides to incertae sedis.

\section{How speciose is Isidoides?}

Four species might be present among the specimens studied here. The paralectotype of Isidoides armata is characterised by very slender polyps and thin, transparent tissue, which contrasts with the thicker tissue and thicker polyps of our southernmost samples. In addition, the paralectotype was collected 4100 and $5600 \mathrm{~km}$ from New Caledonia and New Zealand, respectively, and may belong to a separate biogeographic region (Pante et al. 2012b). However, despite these morphological nuances and the apparent geographic isolation, we do not feel there are sufficient data to assess whether Isidoides armata is a separate species from the specimens sampled further south.

Sequencing of $m t M u t S$ among the newly collected material from New Caledonia and New Zealand revealed the presence of three haplotypes, which are separated by only two silent mutations (i.e. mutations at the nucleotide level that have no impact on the amino acid sequence). While this is a minimal level of genetic differentiation, previous studies have noted that calcaxonians show little intraspecific genetic variation at mitochondrial loci (McFadden et al. 2010, 2011), and Pante and Watling (2012) have suggested that a single mutation at $m t M u t S$ may be used to diagnose species of Chrysogorgia. Specimens representing two of these haplotypes (A and B) are morphologically indistinguishable from each other. Specimens with haplotype $C$, on the other hand, differ from those with haplotypes A and B in characteristics of the axis. Given the extremely low genetic variation measured, and the poor match with morphological variation, we conclude that we have either evidenced intraspecific genetic variation at $m t M u t S$ (which is particularly interesting, because the genetic variants were found in sympatry), or a set of cryptic species (A and B relative to I. armata). Haplotype C might belong to a new, diagnosable species, but the extremely small sample size at hand (two colonies, one successfully genotyped), and lack of genetic variation at other markers compels us to apply the precautionary principle and wait until additional evidence is available before erecting a new species.

\section{Acknowledgements}

We are grateful to Sarah Samadi (MNHN/IRD) for inviting EP to participate on the Terrasses cruise, during which most of the material examined herein was collected. Generous financial support from Paulyn Cartwright (University of Kansas) allowed EP to travel to New Caledonia. The 'Terrasses' cruise, undertaken by the MNHN and the Institut de Recherche pour le Développement (IRD) and organised by Sarah Samadi, is part of the 'Tropical Deep-Sea Benthos' research program (formerly MUSORTSOM), spearheaded by the MNHN and the IRD (Bouchet et al. 2008). We are grateful to the crew of the $R / V$ Alis for contributing to the success of this cruise. We thank Aude Andouche and Philippe Maestrati for their help with the MNHN collections, as well as Elly Beglinger and Rob van 
Publisher: CSIRO; Journal: IS:Invertebrate Systematics

Article Type: research-article; Volume: ; Issue: ; Article ID: IS12053

DOI: 10.1071/IS12053; TOC Head:

Soest from the Zoological Museum of the University of Amsterdam. Specimens from New Zealand were provided by the NIWA Invertebrate Collection, and were collected during the Voyages TAN0308 ('Norfolk Ridge/Lord Howe Rise Marine Biodiversity Discovery Survey (NORFANZ), 'PI Malcom Clark, NIWA), jointly funded by the Australian National Oceans Office and the New Zealand Ministry of Fisheries, TAN0413 ('Bay of Plenty and Hikurangi Plateau Seamounts: their importance to fisheries and marine ecosystems', PI Malcolm Clark, NIWA), and KAH0011 ('Bay of Plenty and southern Kermadec Arc Seamounts Biodiversity survey’, PI Malcolm Clark, NIWA), undertaken by the NIWA and funded by the New Zealand Foundation for Research, Science and Technology with additional funding from the Ministry of Fisheries. Sadie Mills, Kareen Schnabel and Peter Marriott (NIWA) provided curatorial information and photographs of these specimens. John Douzat, Kristina Samples, Tram Lam, Nguyen Loc, Ryan Picard (undergraduates at UL Lafayette), Michael Purpera and Tom Pesacreta (Microscopy Center, UL Lafayette) helped with specimen preparation and microscopy. Financial support was provided by Sigma Xi (Grants-in-Aid of Research Program, award \# GIARG20061021830514629), the American Museum of Natural History (Lerner Gray Fund), the UL Lafayette Graduate Student Organization, the French Société Française d'Écologie (grant for support of fieldwork), and the National Science Foundation, 'Assembling the Cnidarian Tree of Life' (grant to Catherine McFadden, sub-contract to Scott France: EF-0531570; grant to Paulyn Cartwright: EF0531779). All material has been collected under appropriate collection permits and approved ethics guidelines (detailed in Pante et al. 2012a). We thank Jana Thoma, Joris van der Ham and Les Watling for sharing unpublished results. Finally, we thank two anonymous reviewers and the editor of Invertebrate Systematics for significantly improving the manuscript.

\section{References}

$<\mathrm{jrn}>$ Abramoff, M., Magelhaes, P., and Ram, S. (2004). Image processing with ImageJ. Biophotonics International 11, $36-42 .</ \mathrm{jrn}>$

$<$ unknown>Alderslade, P. (1998). Revisionary systematics in the gorgonian family Isididae, with descriptions of numerous new taxa (Coelenterata: Octocorallia). Records of the Western Australian Museum Supplement No. 55. $</$ unknown $>$

$<$ jrn>Alderslade, P., and McFadden, C. S. (2012). A new genus and species of the family Isididae (Coelenterata: Octocorallia) from a CMAR Biodiversity study, and a discussion on the subfamilial placement of some nominal isidid genera. Zootaxa 3154, 21-39. </jrn>

$<$ edb>Bayer, F. (1956). Octocorallia. In: 'Treatise on Invertebrate Paleontology, Volume (F) Coelenterata'. (Ed. R. Moore.) pp. F166-F230. Geological Society of America and the University of Kansas Press, Lawrence, KS, USA. $</$ edb $>$

$<\mathrm{jrn}>$ Bayer, F. (1979). Distichogorgia sconsa, a new genus and species of chrysogorgiid octocoral (Coelenterata: Anthozoa) from the Blake Plateau off Northern Florida. Proceedings of the Biological Society of Washington 92 , 876-882. $</$ jrn $>$ 
Publisher: CSIRO; Journal: IS:Invertebrate Systematics

Article Type: research-article; Volume: ; Issue: ; Article ID: IS12053

DOI: 10.1071/IS12053; TOC Head:

$<\mathrm{jrn}>$ Bayer, F., and Grasshoff, M. (1994). The genus group taxa of the family Ellisellidae, with clarification of the genera established by J. E. Gray (Cnidaria: Octocorallia). Senkenbergiana biologica 74, 21-45.</jrn>

$<$ jrn>Bayer, F., and Stefani, J. (1988). A new species of Chrysogorgia (Octocorallia: Gorgonacea) from New

Caledonia, with descriptions of some other species from the Western Pacific. Proceedings of the Biological

Society of Washington 101, 257-279.</jrn>

<bok>Bayer, F., Grasshoff, M., and Verseveldt, J. (1983). 'Illustrated Trilingual Glossary of Morphological and

Anatomical Terms Applied to Octocorallia.' (E. J. Brill: Leiden, Netherlands.) $</$ bok $>$

$<$ jrn>Bilewitch, J. P., and Degnan, S. M. (2011). A unique horizontal gene transfer event has provided the octocoral mitochondrial genome with an active mismatch repair gene that has potential for an unusual self-contained function. BMC Evolutionary Biology 11, 228. doi:10.1186/1471-2148-11-228</jrn $>$

$<$ edb>Bouchet, P., Héros, V., Lozouet, P., and Maestrati, P. (2008). A quarter-century of deep-sea malacological

exploration in the South and West Pacific: where do we stand? How far to go? In Tropical Deep-Sea Benthos 25

(Eds V. Héros, R. H. Cowie and P. Bouchet.) pp. 9-40.</edb>

$<\mathrm{jrn}>$ Brockman, S. A., and McFadden, C. S. (2012). The mitochondrial genome of Paraminabea aldersladei

(Cnidaria: Anthozoa: Octocorallia) supports intramolecular recombination as the primary mechanism of gene rearrangement in octocoral mitochondrial genomes. Genome Biology and Evolution 4, 994-1006.

doi:10.1093/gbe/evs074</jrn>

$<$ jrn $>$ Brugler, M. R., and France, S. C. (2007). The complete mitochondrial genome of the black coral Chrysopathes formosa (Cnidaria: Anthozoa: Antipatharia) supports classification of antipatharians within the subclass Hexacorallia. Molecular Phylogenetics and Evolution 42, 776-788. doi:10.1016/j.ympev.2006.08.016</jrn>

$<$ jrn>Brugler, M. R., and France, S. C. (2008). The mitochondrial genome of a deep-sea bamboo coral (Cnidaria,

Anthozoa, Octocorallia, Isididae): genome structure and putative origins of replication are not conserved among octocorals. Journal of Molecular Evolution 67, 125-136. doi:10.1007/s00239-008-9116-2</jrn>

$<$ jrn $>$ Chen, C., Chiou, C., Dai, C., and Chen, C. (2008a). Unique mitogenomic features in the scleractinian family

Pocilloporidae (Scleractinia: Astrocoeniina). Marine Biotechnology (New York, N.Y.) 10, 538-553.

doi:10.1007/s10126-008-9093-x</jrn>

$<$ jrn $>$ Chen, C., Dai, C., Plathong, S., Chiou, C., and Chen, C. (2008b). The complete mitochondrial genomes of needle corals, Seriatopora spp. (Scleractinia: Pocilloporidae): an idiosyncratic atp8, duplicated trnW gene, and hypervariable regions used to determine species phylogenies and recently diverged populations. Molecular Phylogenetics and Evolution 46, 19-33. doi:10.1016/j.ympev.2007.09.013</jrn>

<jrn>D’Onorio de Meo, P., D’Antonio, M., Griggio, F., Lupi, R., Borsani, M., Pavesi, G., Castrignanò, T., Pesole, G., and Gissi, C. (2012). MitoZoa 2.0: a database resource and search tools for comparative and evolutionary analyses of mitochondrial genomes in Metazoa. Nucleic Acids Research 40, D1168-D1172. doi:10.1093/nar/gkr1144</jrn> 
Publisher: CSIRO; Journal: IS:Invertebrate Systematics

Article Type: research-article; Volume: ; Issue: ; Article ID: IS12053

DOI: 10.1071/IS12053; TOC Head:

$<$ jrn $>$ Flot, J., and Tillier, S. (2007). The mitochondrial genome of Pocillopora (Cnidaria: Scleractinia) contains two variable regions: the putative D-loop and a novel ORF of unknown function. Gene 401, 80-87. doi:10.1016/j.gene.2007.07.006</jrn>

$<$ jrn $>$ France, S. C. (2007). Genetic analysis of bamboo corals (Cnidaria: Octocorallia: Isididae): does lack of colony branching distinguish Lepidisis from Keratoisis? Bulletin of Marine Science 81, 323-333.</jrn>

$<$ jrn $>$ France, S. C., and Hoover, L. L. (2002). DNA sequences of the mitochondrial COI gene have low levels of divergence among deep-sea octocorals (Cnidaria: Anthozoa). Hydrobiologia 471, 149-155. doi:10.1023/A:1016517724749</jrn>

$<$ jrn>France, S. C., Rosel, P. E., Agenbroad, J. E., Mullineaux, L. S., and Kocher, T. D. (1996). DNA sequence variation of mitochondrial large-subunit rRNA provides support for a two-subclass organization of the Anthozoa (Cnidaria). Molecular Marine Biology and Biotechnology 5, 15-28.</jrn>

$<$ jrn>Hebert, P. D. N., Cywinska, A., Ball, S. L., and deWaard, J. R. (2003). Biological identifications through DNA barcodes. Proceedings. Biological Sciences 270, 313-321. doi:10.1098/rspb.2002.2218</jrn>

$<\mathrm{jrn}>$ Katoh, K., and Toh, H. (2008). Recent developments in the MAFFT multiple sequence alignment program. Briefings in Bioinformatics 9, 286-298. doi:10.1093/bib/bbn013</jrn>

<jrn>Katoh, K., Misawa, K., Kuma, K.-i., and Miyata, T. (2002). MAFFT: a novel method for rapid multiple sequence alignment based on fast Fourier transform. Nucleic Acids Research 30, 3059-3066. doi:10.1093/nar/gkf436 $</$ jrn $>$

$<$ jrn>Kayal, E., and Lavrov, D. (2008). The mitochondrial genome of Hydra oligactis (Cnidaria, Hydrozoa) sheds new light on animal mtDNA evolution and cnidarian phylogeny. Gene 410, 177-186. doi:10.1016/j.gene.2007.12.002 $</$ jrn $>$

$<$ jrn>Kayal, E., Bentlage, B., Collins, A. G., Kayal, M., Pirro, S., and Lavrov, D. V. (2012). Evolution of linear mitochondrial genomes in medusozoan cnidarians. Genome Biology and Evolution 4, 1-12. doi:10.1093/gbe/evr123</jrn $>$

$<\mathrm{jrn}>$ Kimura, M. (1980). A simple method for estimating evolutionary rates of base substitutions through comparative studies of nucleotide-sequences. Journal of Molecular Evolution 16, 111-120. doi:10.1007/BF01731581</jrn>

$<$ jrn>Lupi, R., de Meo, P. D., Picardi, E., D’Antonio, M., Paoletti, D., Castrignanò, T., Pesole, G., and Gissi, C. (2010). MitoZoa: a curated mitochondrial genome database of metazoans for comparative genomics studies. Mitochondrion 10, 192-199. doi:10.1016/j.mito.2010.01.004</jrn>

$<$ jrn $>$ McFadden, C. S., France, S. C., Sánchez, J. A., and Alderslade, P. (2006). A molecular phylogenetic analysis of the Octocorallia (Cnidaria: Anthozoa) based on mitochondrial protein-coding sequences. Molecular Phylogenetics and Evolution 41, 513-527. doi:10.1016/j.ympev.2006.06.010</jrn> 
Publisher: CSIRO; Journal: IS:Invertebrate Systematics

Article Type: research-article; Volume: ; Issue: ; Article ID: IS12053

DOI: 10.1071/IS12053; TOC Head:

$<\mathrm{jrn}>$ McFadden, C. S., Sánchez, J. A., and France, S. C. (2010). Molecular phylogenetic insights into the evolution of Octocorallia: a review. Integrative and Comparative Biology 50, 389-410. doi:10.1093/icb/icq056</jrn>

$<$ jrn $>$ McFadden, C. S., Benayahu, Y., Pante, E., Thoma, J. N., Nevarez, P. A., and France, S. C. (2011). Limitations of mitochondrial gene barcoding in Octocorallia. Molecular Ecology Resources 11, 19-31. doi:10.1111/j.1755$\underline{0998.2010 .02875 . x}</ \mathrm{jrn}>$

$<$ bok>Nei, M., and Kumar, S. (2000). 'Molecular Evolution and Phylogenetics.' (Oxford University Press: Oxford, UK. $)</$ bok $>$

$<$ unknown>Nutting, C. (1910). The Gorgonacea of the Siboga Expedition VI. The Gorgonellidae. Siboga-Expeditie. Monograph XIIIb3.</unknown>

$<$ jrn>Pante, E., and France, S. C. (2010). Pseudochrysogorgia bellona n. gen. n. sp.: a new genus and species of chrysogorgiid octocoral (Coelenterata: Anthozoa) from the Coral Sea. Zoosystema 32, 595-612. doi:10.5252/z2010n4a4</jrn>

$<$ jrn $>$ Pante, E., and Watling, L. (2012). Chrysogorgia from the New England and Corner Seamounts: AtlanticPacific connections. Journal of the Marine Biological Association of the United Kingdom 92, 911-927. doi:10.1017/S0025315411001354</jrn>

$<$ jrn>Pante, E., France, S. C., Couloux, A., Cruaud, C., McFadden, C. S., Samadi, S., and Watling, L. (2012a).

Deep-sea origin and in-situ diversification of chrysogorgiid octocorals. PLOS ONE 7, e38357. doi:10.1371/journal.pone.0038357</jrn>

$<$ jrn>Pante, E., Corbari, L., Thubaut, J., Chan, T.-Y., Mana, R., Boisselier, M.-C., Bouchet, P., and Samadi, S. (2012b). Exploration of the deep-sea fauna of Papua New Guinea. Oceanography (Washington, D.C.) 25, 214 225. doi:10.5670/oceanog. $2012.65</$ jrn $>$

$<$ bok>Paradis, E. (2006). 'Analysis of Phylogenetics and Evolution in R.' (Springer, NY, USA.)</bok >

$<$ jrn>Park, E., Song, J.-I., and Won, Y.-J. (2011). The complete mitochondrial genome of Calicogorgia granulosa

(Anthozoa: Octocorallia): potential gene novelty in unidentified ORFs formed by repeat expansion and segmental duplication. Gene 486, 81-87. doi:10.1016/j.gene.2011.07.003</jrn>

$<$ eref $>$ R Development Core Team (2012). R: A Language and Environment for Statistical Computing. R Foundation for Statistical Computing, Vienna, Austria. Available at: http://www.R-project.org (Verified 17 May

$2013)</$ eref $>$

$<$ eref>Rasband, W. (1997-2008). ImageJ. Technical report, U.S. National Institutes of Health, Bethesda, Maryland, USA. Available at: http://rsbweb.nih.gov/ij/ (Verified 17 May 2013)</eref>

$<$ jrn>Sánchez, J. A., McFadden, C. S., France, S. C., and Lasker, H. R. (2003). Molecular phylogenetic analyses of shallow-water Caribbean octocorals. Marine Biology 142, 975-987.</jrn> 
Publisher: CSIRO; Journal: IS:Invertebrate Systematics

Article Type: research-article; Volume: ; Issue: ; Article ID: IS12053

DOI: 10.1071/IS12053; TOC Head:

$<$ jrn>Uda, K., Komeda, Y., Koyama, H., Koga, K., Fujita, T., Iwasaki, N., and Suzuki, T. (2011). Complete mitochondrial genomes of two Japanese precious corals, Paracorallium japonicum and Corallium konojoi (Cnidaria, Octocorallia, Coralliidae): notable differences in gene arrangement. Gene 476, 27-37.

doi:10.1016/j.gene.2011.01.019</jrn>

$<$ jrn> van der Ham, J., Brugler, M. R., and France, S. C. (2009). Exploring the utility of an indel-rich, mitochondrial intergenic region as a molecular barcode for bamboo corals (Octocorallia: Isididae). Marine Genomics 2, 183192. doi:10.1016/j.margen.2009.10.002</jrn>

$<$ eref $>$ Williams, A., Gowlett-Holmes, K., and Althaus, F. (2006). Biodiversity survey of seamounts and slopes of the Norfolk Ridge and Lord Howe Rise. Final report to the Department of the Environment and Heritage (National Oceans Office). Available at: http://www.environment.gov.au/coasts/discovery/publications/norfanzvoyage-report.html (Verified 17 May 2013)</eref $>$

Fig. 1. Map of the south-western Pacific, with the sampling locations of the Isidoides armata Nutting, 1910 paralectotype (square), the new specimens used in this study (circles), and an additional specimen from the collection of the Northern Territory Museum identified as Isidoides armata by Phil Alderslade (triangle; registration number C014597, Norfanz station TAN 0308 58/10 sampled on May 21, 2003 at 29¹1'56.4"S, 158 58'58.8'E, 728-826 m depth). Contour lines represent the $2000 \mathrm{~m}$ depth isobath.

Fig. 2. Nutting's original illustration of Isidoides armata Nutting, 1910, with original figure numbering. (2) Branch, $15 \mathrm{~cm}$ long and $5 \mathrm{~cm}$ wide; (2a) branch and polyp close-up; (5) sclerites (for scale, 5e is $454.5 \mu \mathrm{m}$ tall).

Fig. 3. Isidoides armata Nutting, 1910, paralectotype (ZMA Coel. 02711): (A) damaged fragment with few remaining polyps; scars on the branch coenenchyme indicate that many polyps have fallen off the colony; $(B)$ closeup of the area of the branch enclosed in dashed box, showing polyps and a feature resembling a proteinaceous node (arrow); (C) SEM of polyp.

Fig. 4. Colony fragments of Isidoides armata Nutting, 1910 from recent collection, after tissue fixation in ethanol. (A) Specimen NOR220652 (haplotype A) from the Norfolk Ridge, off New Caledonia; $(B)$ close-up of the area of the branch enclosed in dashed box; flipped over to show a feature resembling a proteinaceous node (arrow); $(C)$ specimen TER10084 (haplotype B). (D) specimen TER1051 (haplotype A); E, TER20516 (haplotype B). All 'TER' specimens were collected during the Terrasses cruise, on the Norfolk and Loyalty Ridges off New Caledonia. See Table 1 for details on haplotypes.

Fig. 5. Colony fragment of Isidoides armata Nutting, 1910 (TER1062; haplotype A/C) from the Loyalty Ridge, off New Caledonia. The photograph was taken soon after collection, before immersion in ethanol: $(A)$ whole fragment (note the dark axis); $(B)$ close-up of the area of the branch enclosed in black box. See Table 1 for details on haplotypes.

Fig. 6. Boxplots representing the distribution of genetic distances (Kimura-2-Parameter, or K2P) among calcaxonian corals, based on the $5^{\prime}$ end of $m t M u t S$ (alignment length 969 bp). Shown are the minimum, first quartile, 
Publisher: CSIRO; Journal: IS:Invertebrate Systematics

Article Type: research-article; Volume: ; Issue: ; Article ID: IS12053

DOI: 10.1071/IS12053; TOC Head:

median (bolded line), third quartile, and maximum values. Statistical outliers ( $>1.5 \times$ the inter-quartile range) are presented as open circles. Far left: inter-familial distances between MCC chrysogorgiids (Pante et al. 2012a), primnoids and isidids (Clade S1 and Keratoisidinae only). Far right: intra-familial, inter-generic distances among the same groups of taxa. Middle: distances between Isidoides haplotypes (A and B) and isidids (Clade S1 and Keratoisidinae). The number of unique pairwise distances is indicated above each boxplot. Databased on 48 sequences (calcaxonian dataset published in McFadden et al. 2011, plus our two Isidoides and isidid Clade S1 haplotypes).

Fig. 7. Phylogenetic position of, and mitochondrial protein-coding gene order observed in, Isidoides armata Nutting, 1910, compared with other calcaxonians. Left: phylogenetic placement of Isidoides among calcaxonians (reproduced from Pante et al. 2012a), based on the 5' end of mtMutS, coxl and 18S (topology inferred with PhyML and rooted to the Pennatulacea and the Ellisellidae, following the results of McFadden et al. 2006; asterisks denote bootstrap node support $>70 \%$ ). The relationships among Isidoides, the isidid S1 clade, the Keratoisidinae, and their placement within the Calcaxonia, are all well supported (details in Pante et al. 2012a). Right: corresponding inferred mitochondrial protein-coding gene order highlighting the gene junctions tested (extremities are linked, as the mitochondrial genome is a circular molecule in octocorals). Segments are oriented relative to translational direction. Molecular data were obtained from all specimens, except the type, from which DNA could not be amplified.

Fig. 8. Isidoides armata Nutting, 1910, axial skeleton. $(A)$ cross-section of the distal end of a twig (light microscope images; from left to right: CP38321, CP38321, TER20516); (B) exterior of the distal end of a twig (SEM images; CP38321); (C) exterior of a twig (SEM images, TER1061).

Fig. 9. Isidoides armata Nutting, 1910. Specimen TER1051 (haplotype A): (A) sclerites from tentacles (with, on the bottom left, a close-up of the extremity of a rod and its fine structure); $(B)$ sclerites from the body wall (with, on the bottom right, a close-up of the fine structure of a rod).

Fig. 10. Isidoides armata Nutting, 1910: $(A)$ coenenchymal sclerites from specimen TER1051 (haplotype A); $(B)$ polyps (TER1051, left and right, and TER20516 (haplotype B), middle); (C) close-up of distal end of polyp showing tentacles folded over the oral disk (TER20516, same polyp from two different angles).

Table 1. List of specimens used in this study, and the paralectotype (the station information from Nutting 1910 is used here and in further biogeographic discussion; see 'Materials and methods' section for details)

Hap., mtMutS haplotype, based on the $5^{\prime}$ and $3^{\prime}$ ends of the gene. *DNA could not be amplified and sequenced. A/C: only the 5 ' end of the $m t M u t S$ gene could be sequenced, and it could therefore not be assessed whether the individual was characterised by haplotype A or C. The columns ' $m t M u t S$ ', 'coxl' and ' $18 \mathrm{~S}$ ' contain GenBank accession numbers

\begin{tabular}{|c|c|c|c|c|c|c|c|c|}
\hline Specimen & $\begin{array}{l}\text { Voucher } \\
\text { Number }\end{array}$ & $m t M u t S$ & $\operatorname{cox} 1$ & $18 \mathrm{~S}$ & Hap. & $\begin{array}{l}\text { Axial } \\
\text { skeleton }\end{array}$ & Sampling location & Cruise \\
\hline
\end{tabular}


Publisher: CSIRO; Journal: IS:Invertebrate Systematics

Article Type: research-article; Volume: ; Issue: ; Article ID: IS12053

DOI: $10.1071 /$ IS12053; TOC Head:

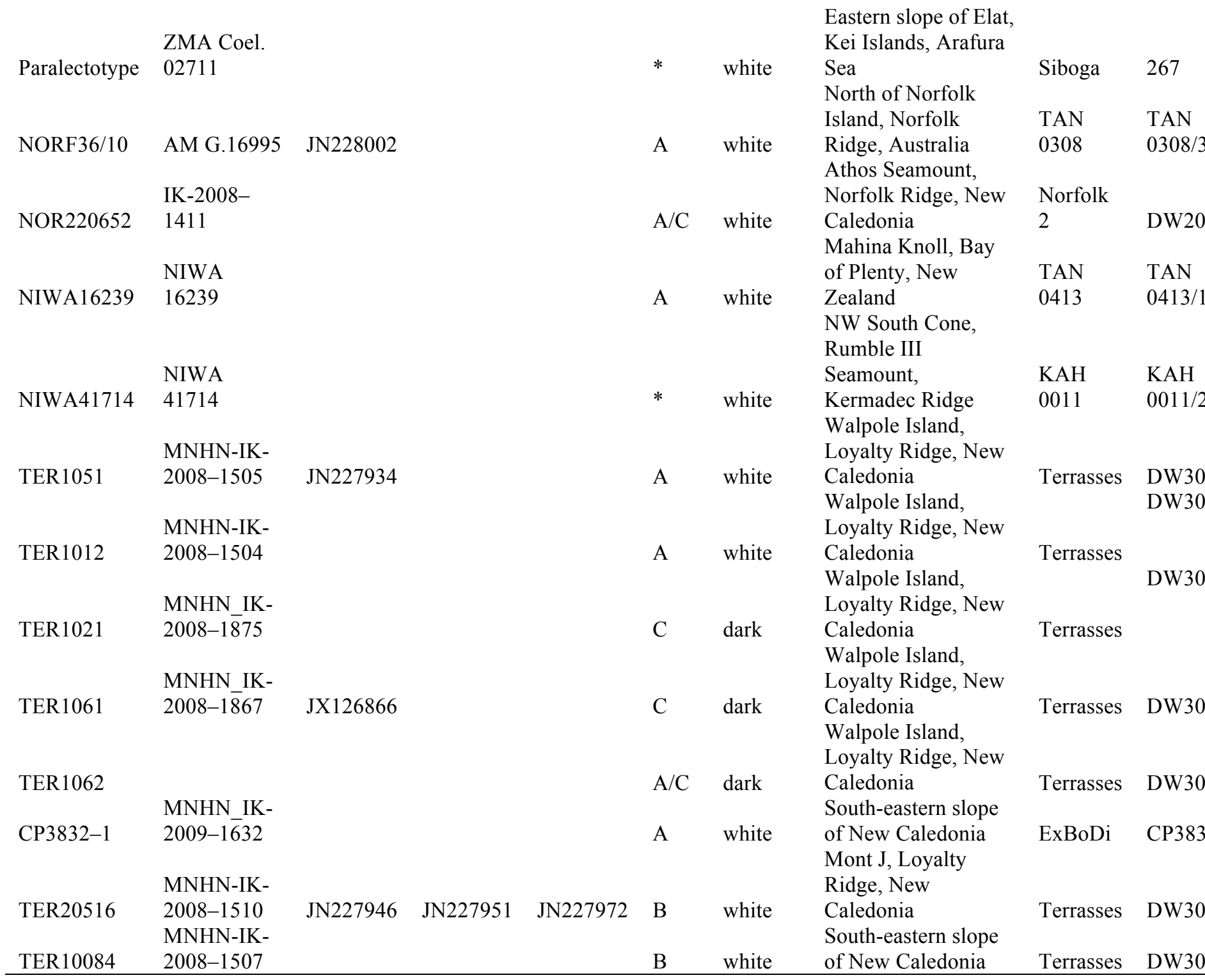

\section{Table 2. Primers used to test mitochondrial gene boundaries and GenBank accession numbers for} the sequences obtained at these gene junctions

*while this sequence was produced using a reverse primer priming in $16 \mathrm{~S}$, it does not contain $16 \mathrm{~S}$

\begin{tabular}{|c|c|c|c|c|c|c|}
\hline Gene 1 & Gene 2 & Primer 1 & Sequence of primer 1 & Reference primer 1 & Primer 2 & Sequence of prin \\
\hline nad4L & mtMutS & ND4L2475F & tagttttactggcetctac & $\begin{array}{l}\text { Brugler and France } \\
\text { (2008) }\end{array}$ & MUT3458R & tsgagcaaaagccact \\
\hline$m t M u t S$ & $16 S$ & MSH4759F & tgtagctcatgatattag & $\begin{array}{l}\text { France }(2007) \\
\text { France and Hoover }\end{array}$ & $16 \mathrm{~S} 5 \mathrm{PR}$ & tcacgtcettaccgata \\
\hline $\operatorname{cox} 1$ & $\cos 2$ & COIoctR & atcatagcatagaccatacc & $(2002)$ & COII8068xF & ccataacaggrctwg \\
\hline$c o b$ & $\operatorname{cox} 3$ & CYTB3741R & gtccgttttcatgtagcttcc & $\begin{array}{l}\text { van der Ham and France, } \\
\text { unpubl. } \\
\text { van der Ham and France, }\end{array}$ & CO3Bam5657F & getgctagttggtattg \\
\hline$c o b$ & $n d 6$ & CYTBGen402F & gattaccggaatattcttagctatgc & unpubl. & ND64699R & ggattcggcgtagata \\
\hline
\end{tabular}


Publisher: CSIRO; Journal: IS:Invertebrate Systematics Article Type: research-article; Volume: ; Issue: ; Article ID: IS12053 DOI: 10.1071/IS12053; TOC Head:

nadl nad4 ND13209F van der Ham and France, unpubl.
ND4 gen4974F taggyttatttactcata 
Figure 1.

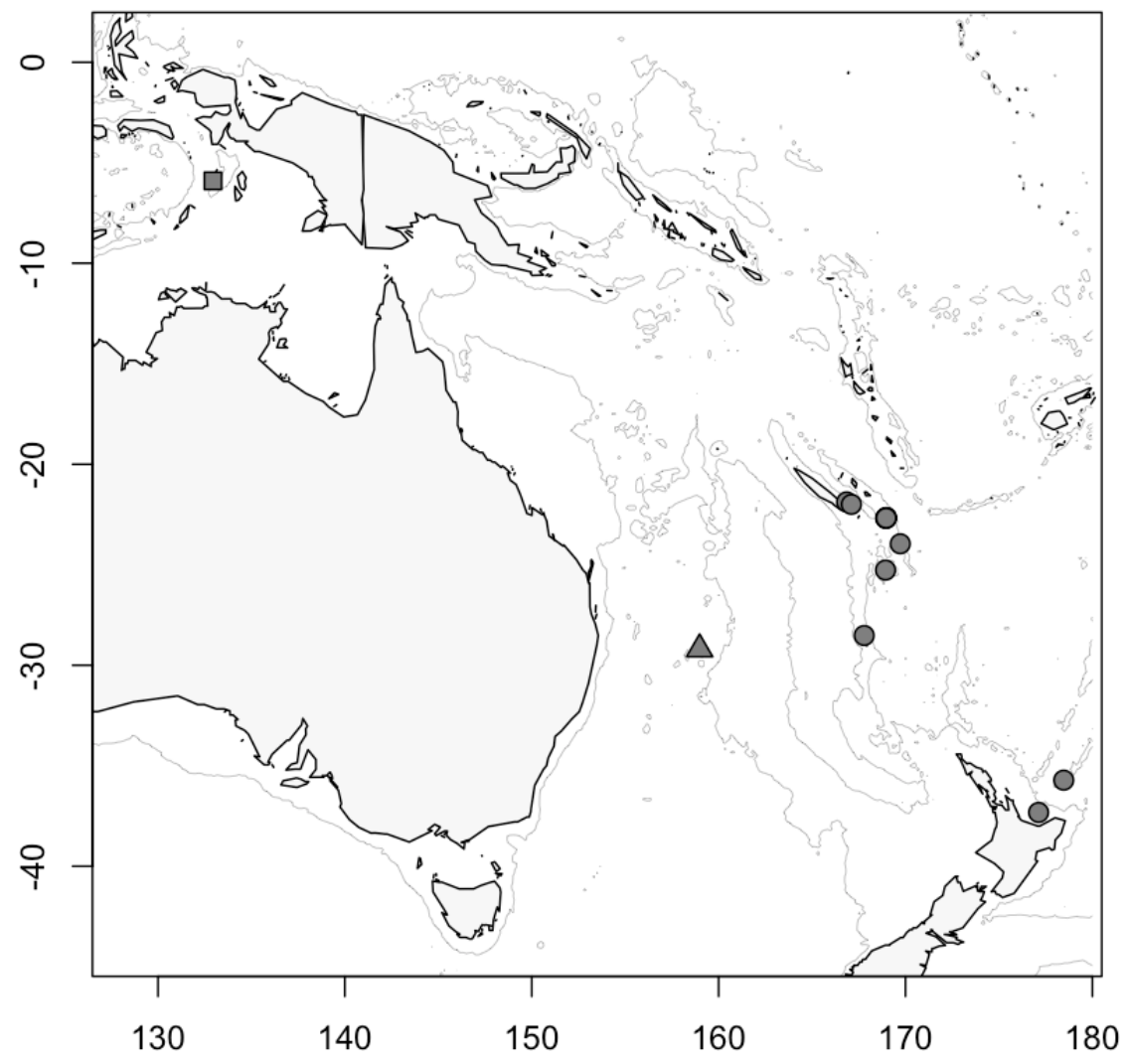

2 
3 Figure 2.

4

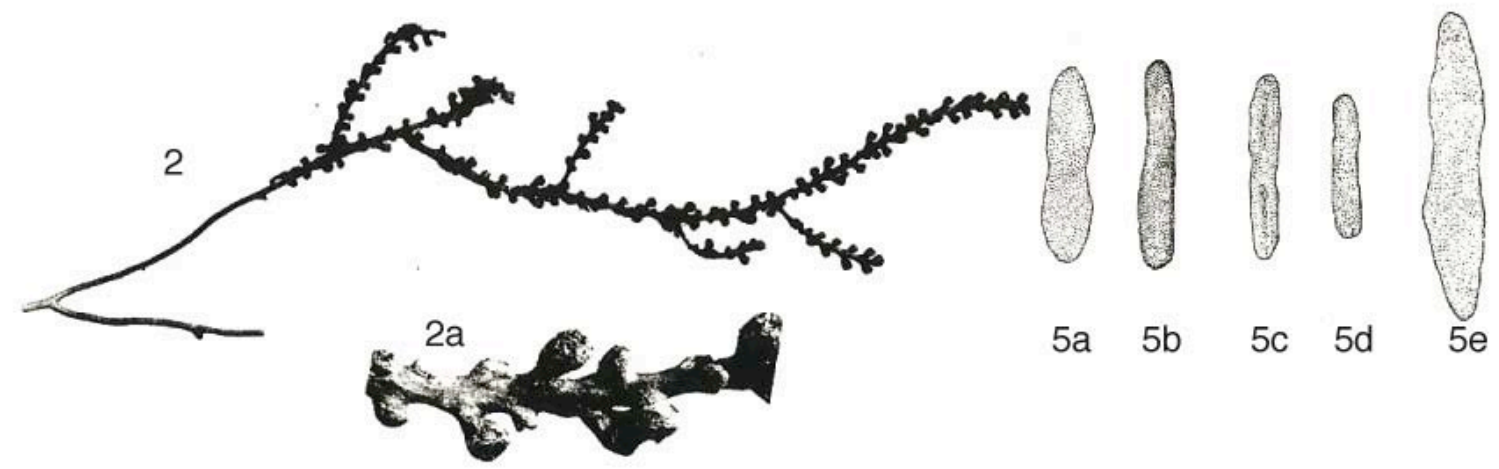


$6 \quad$ Figure 3.

7
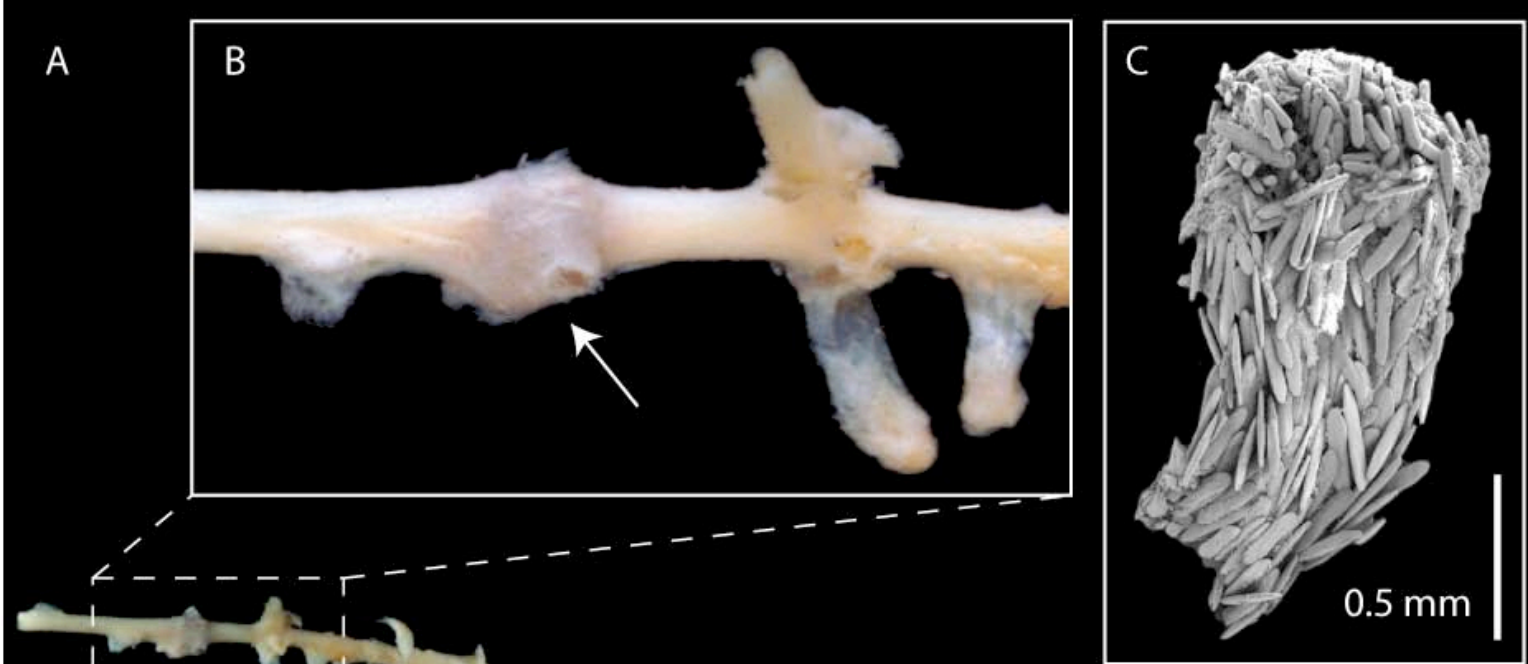

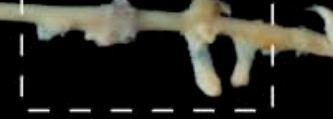
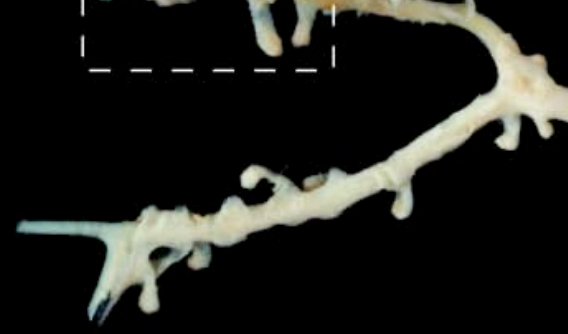
$9 \quad$ Figure 4.

10

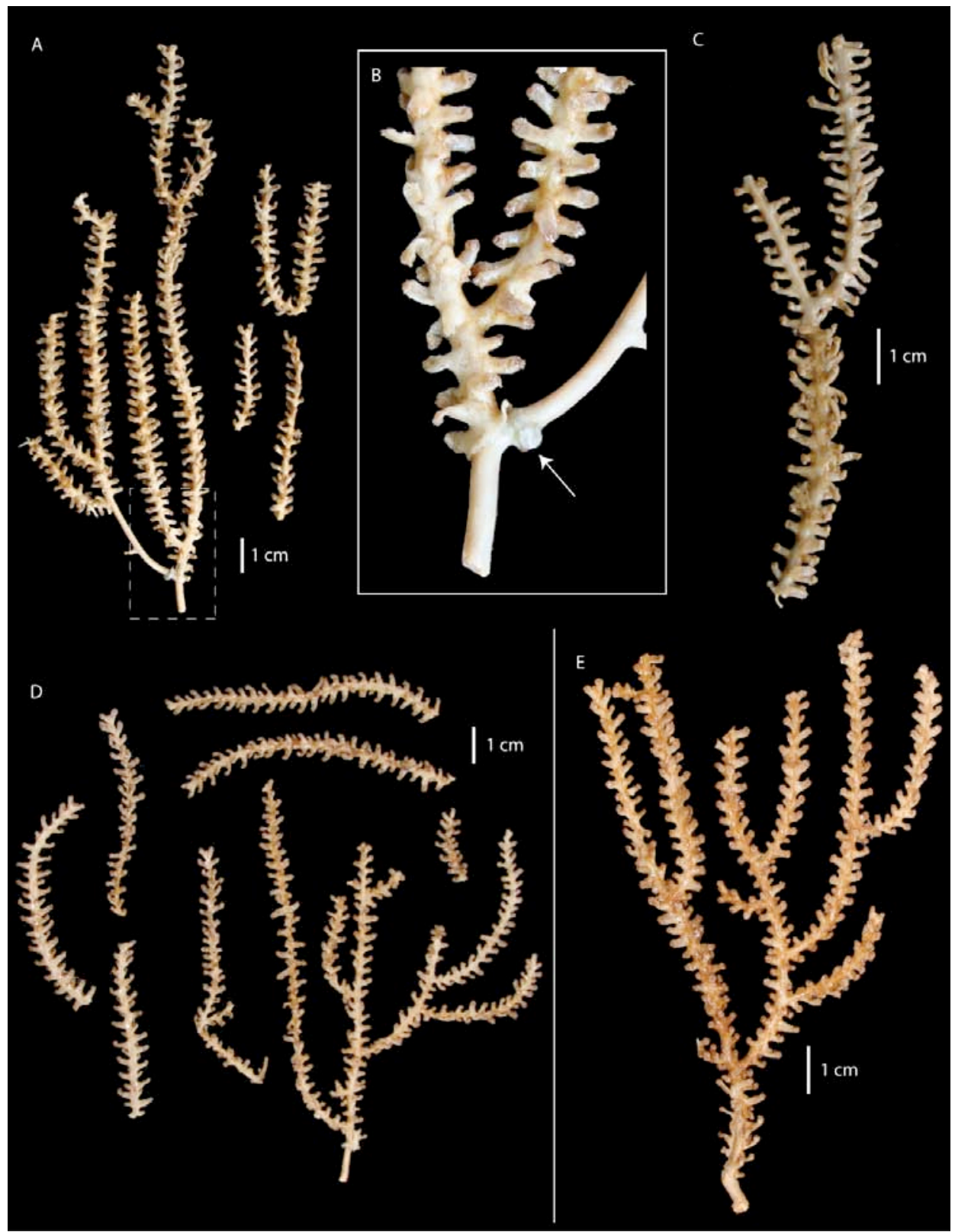


$12 \quad$ Figure 5.

13

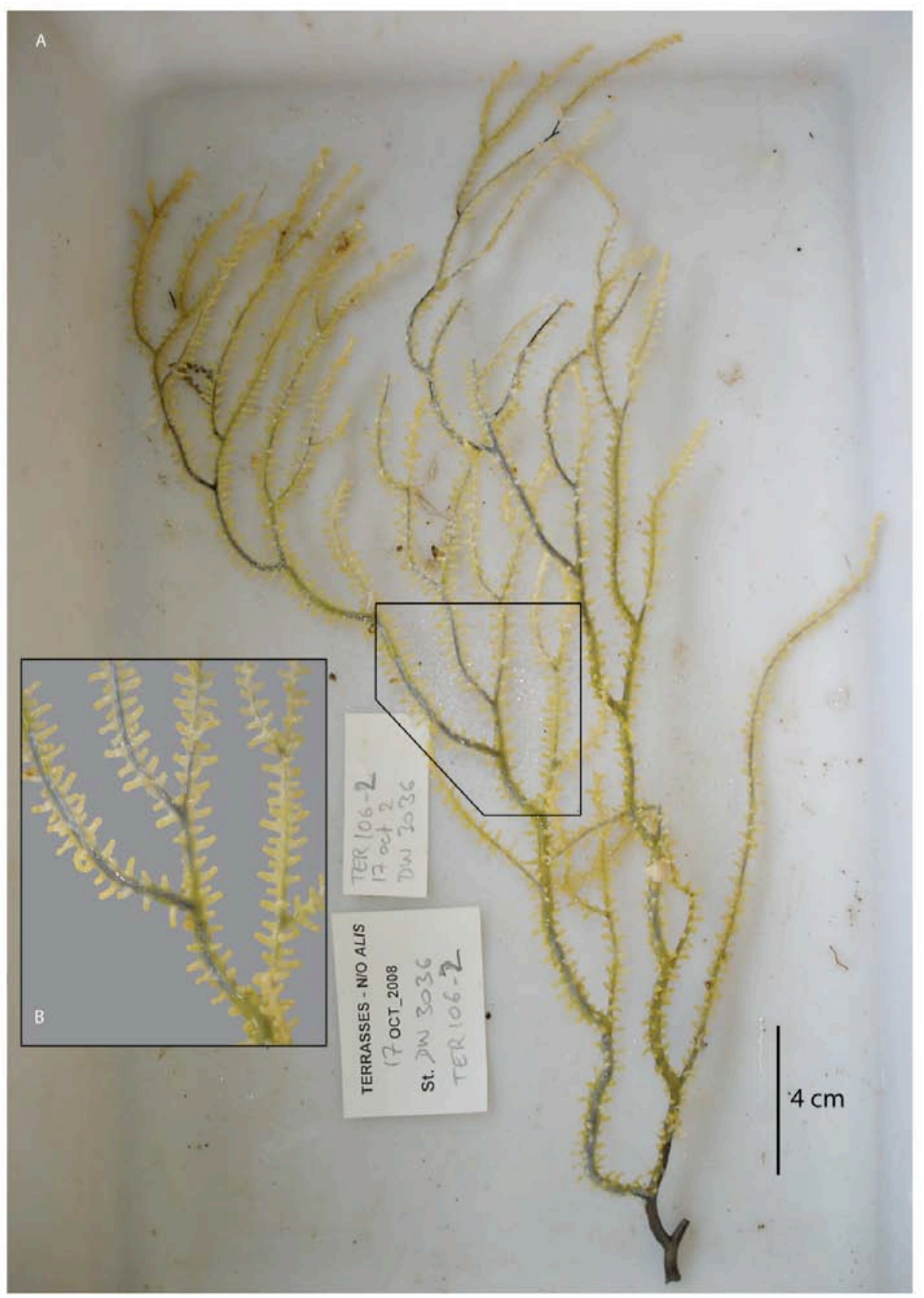

14

15 
$15 \quad$ Figure 6.

16

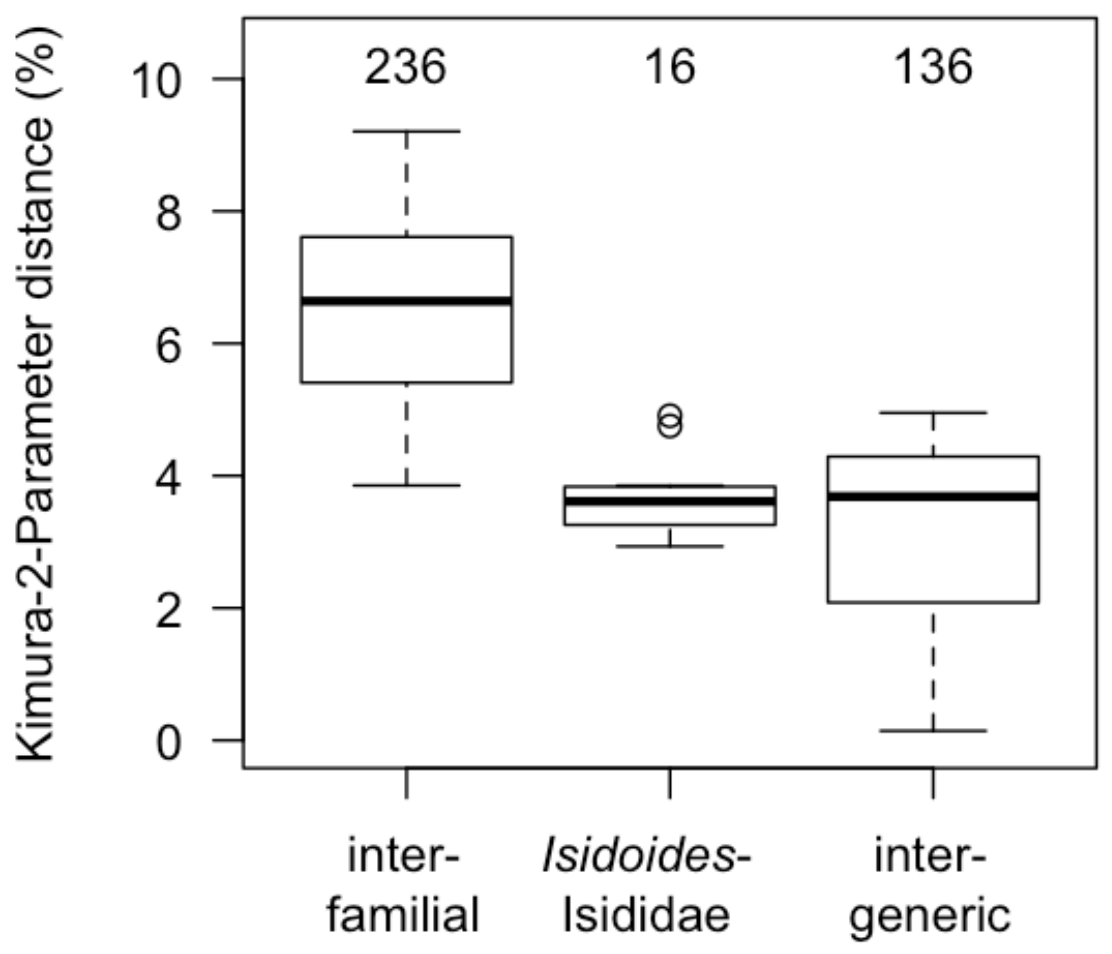

17 


\section{$18 \quad$ Figure 7.}

19

20

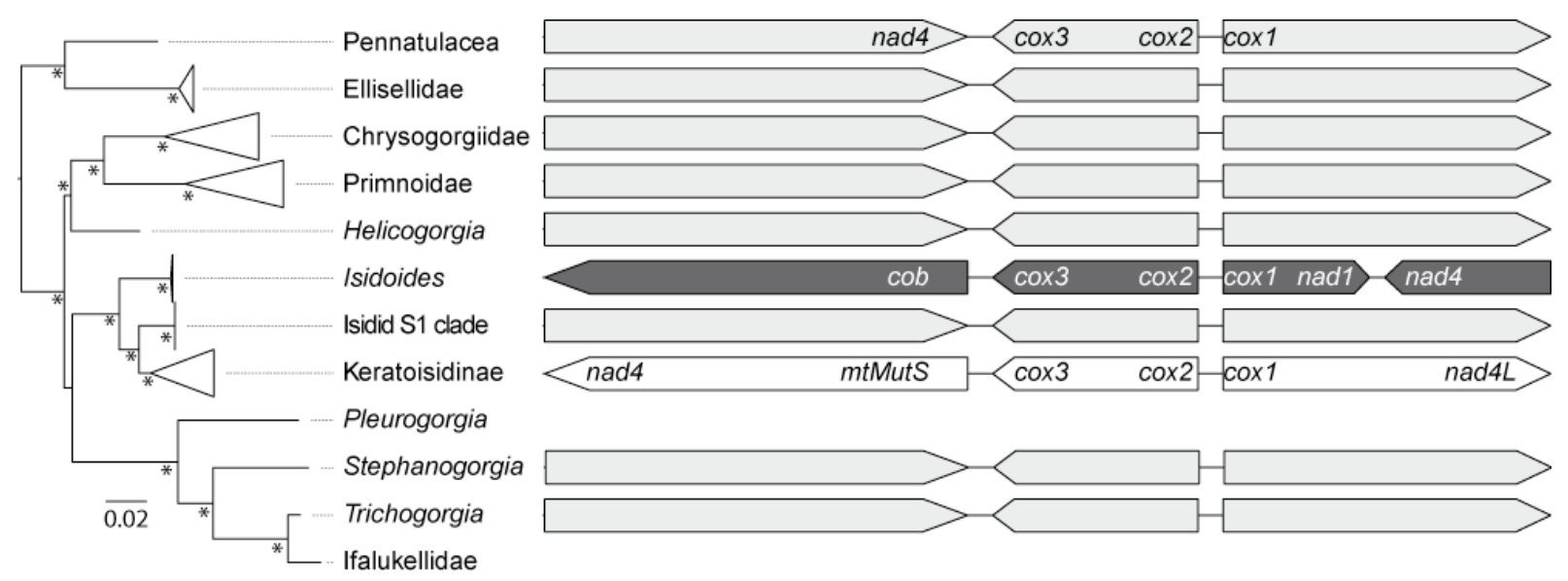

21

22 
$22 \quad$ Figure 8.

23
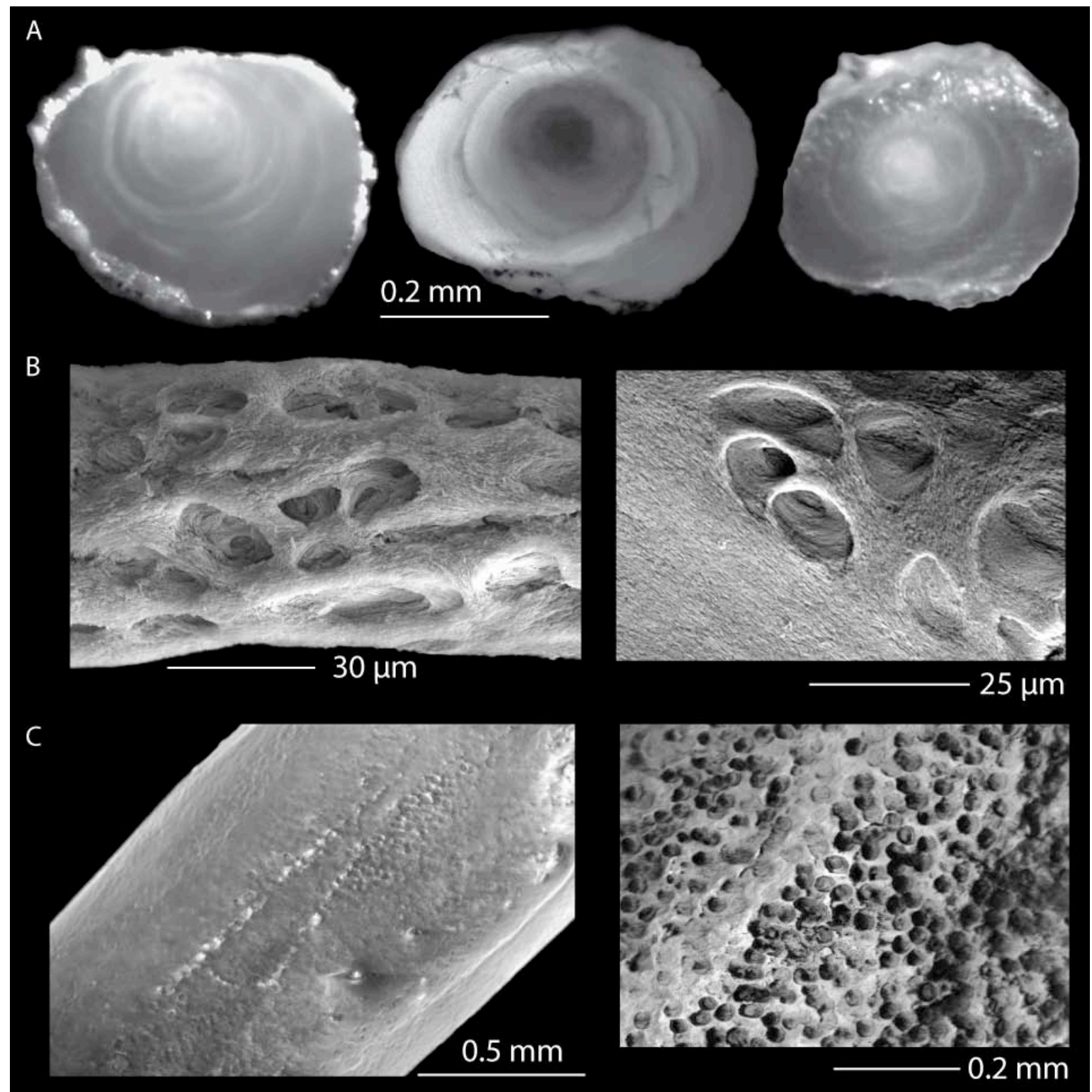
$25 \quad$ Figure 9.

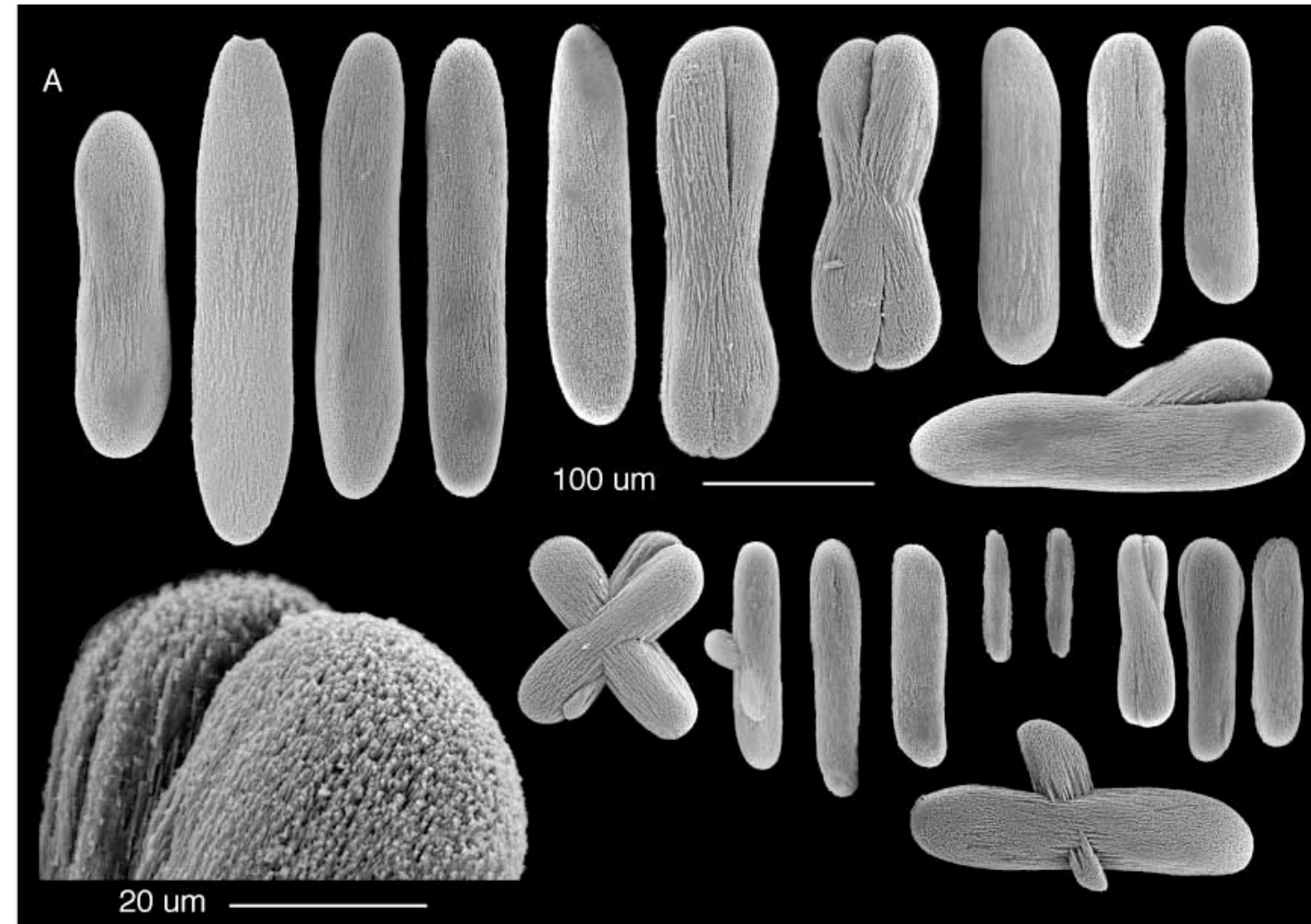

B

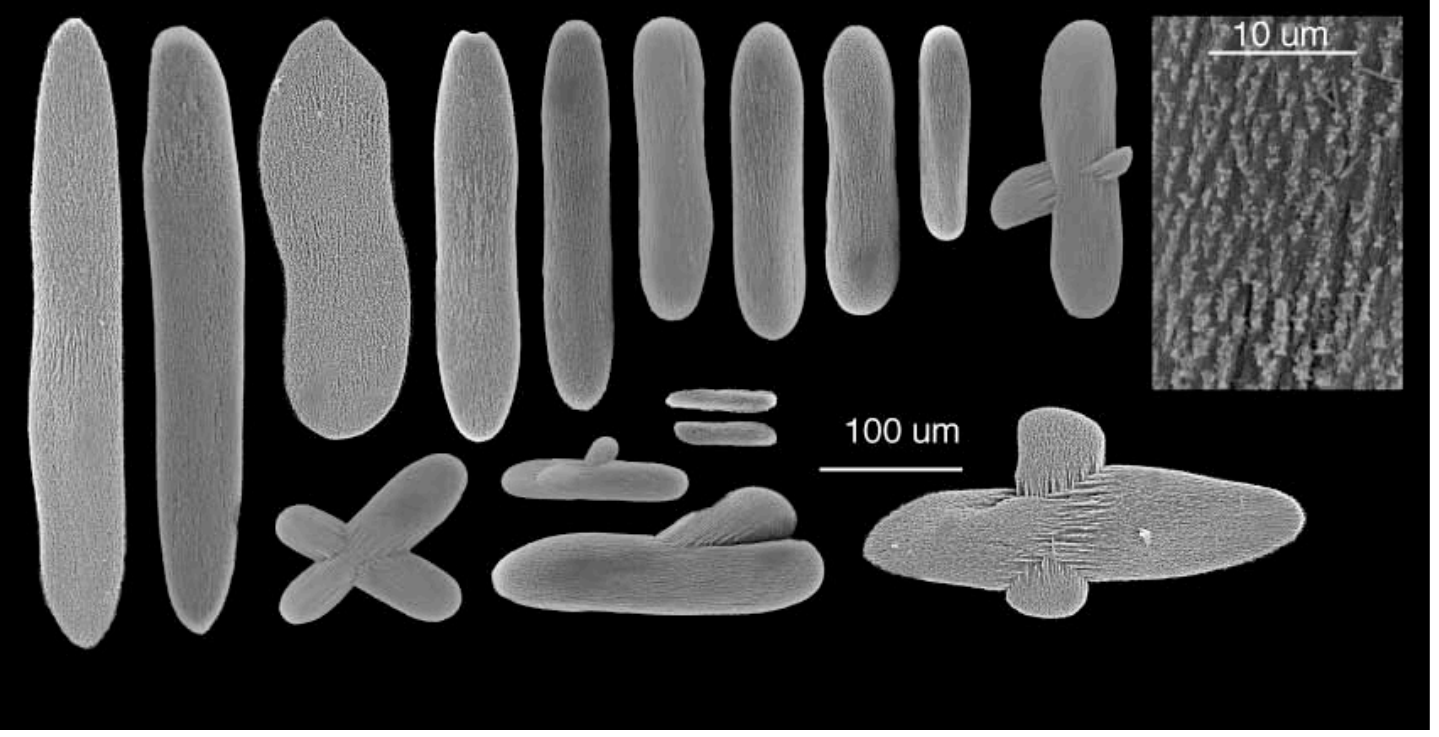


Figure 10.

28

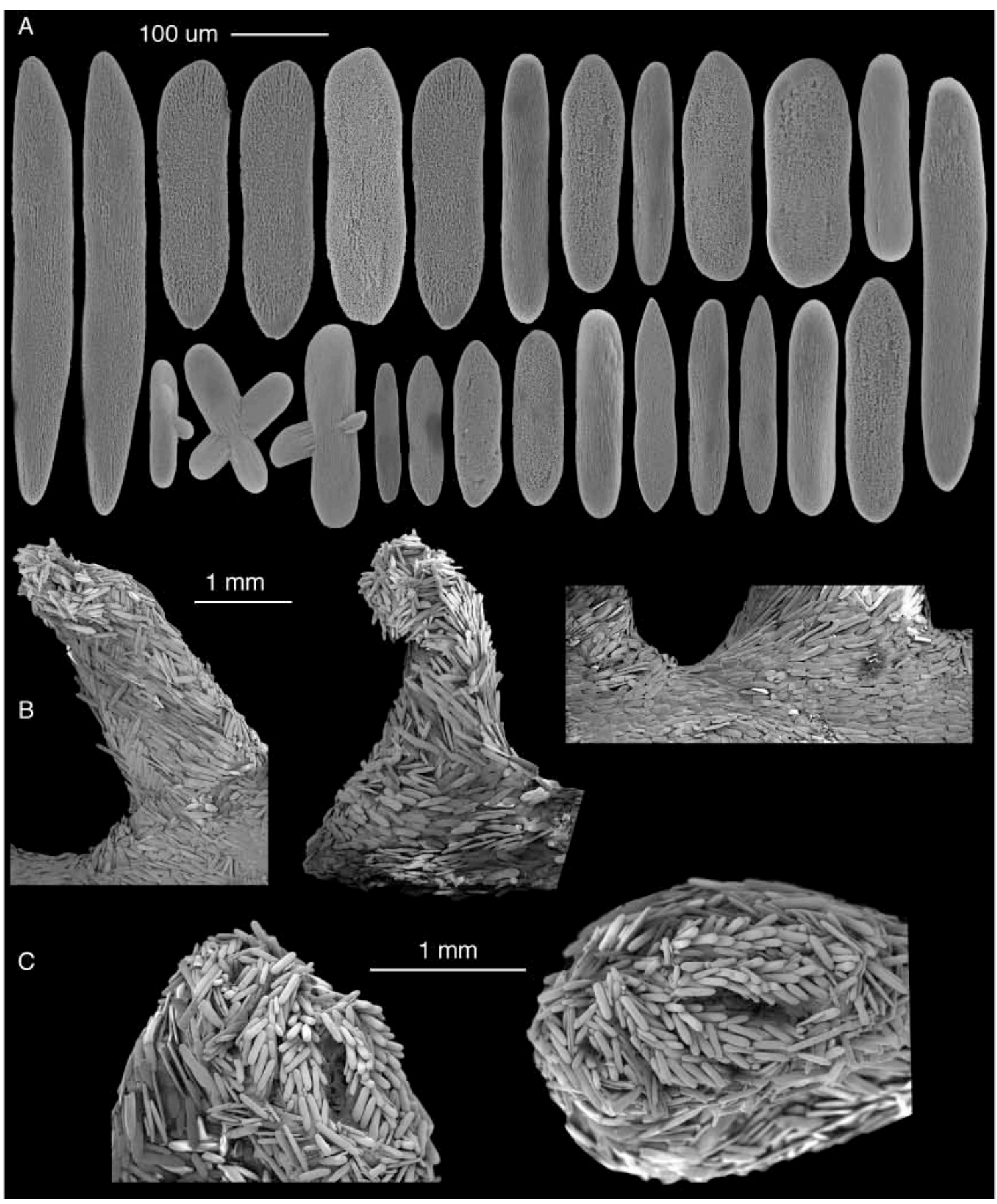

